Chirurgia (2020) 115: 373-379

No. 3, May - June

Copyright@ Celsius

http://dx.doi.org/10.21614/chirurgia.115.3.373

\title{
The Value of Endoscopy as a Predictive Factor when Evaluating the Clinical Response to Neoadjuvant Chemoradiotherapy for Patients with Rectal Cancer
}

\author{
lustinian Bengulescu, Petru Radu*, Cristian lorga, Mircea Bratucu, Costin Pasnicu, Dragos Garofil, \\ Florian Popa, Victor Strambu
}

Department of Surgery, Carol Davila Clinical Hospital of Nephrology, Bucharest, Romania

*Corresponding author:

Petru Radu, MD

Department of Surgery

Carol Davila Clinical Hospital of

Nephrology, Bucharest, Romania

E-mail: drradupetru@yahoo.com
Received: 20.03.2020

Accepted: 27.05 .2020

\section{Rezumat}

Valoarea endoscopiei ca și factor predictiv al răspunsului clinic la radio-chimioterapia neoadjuvantă pentru pacienții cu cancer rectal

Introducere: Tratamentul cancerului rectal, cuprinde radiochimioterapia neaodjuvantă (nCRT), conform ghidurilor internaționale. Literatura de specialitate corelează un mai bun răspuns la radio-chimioterapia neaodjuvantă (regresie tumorală) cu o mai bună rată de supraviețuire la distanță şi supraviețire „cancer free”. Răspunsul tumoral după terapia neoadjuvantă se evaluează fie ca şi răspuns clinic fie ca ți răspuns patologic. Răspunsul clinic este evaluat prin tuşeu rectal, endoscopie (cu sau fără ecografie transrectală) sau prin metode imagistice. Obiectivul nostru a fost de a identifica eventuala valoare predictivă a endoscopiei, ca şi parametru al răspunsului clinic la radio-chimioterapia neoadjuvantă.

Metodă: Am realizat un studiu retrospectiv pe 43 de pacienți tratați pentru cancer rectal în clinica noastră după radiochimioterapie neoadjuvantă. Pacienții au fost împărțiți în două grupuri conform evaluării endoscopice.

Rezulate: Pacienții care au prezentat un răspuns mai bun după radio-chimioterapia neaodjuvantă (scor endoscopic bun) au fost asociați cu o rată mai bună de supraviețuire la distanță şi rată redusă de recidivă în comparație cu pacientii care au prezentat un scor endoscopic slab (86,5\% comparativ cu 56,6\%) şi respectiv (10.34\% comparativ cu $42,85 \%$ ).

Concluzie:Cercetări suplimentare sunt necesare pentru a determina cea mai bună metodă de evaluare a răspunsului clinic post radio- 
chimioterapie neoadjuvantă pentru pacienții cu cancer rectal, dar endoscopia ar putea fi considerată o metodă utilă în acest scop.

Cuvinte cheie: cancer rectal cancer, terapie neodjuvantă, radio-chimioterapie, endoscopie

\begin{abstract}
Introduction: Standard treatment rectal cancer according to numerous international guidelines recommends neoadjuvant chemoradiotherapy (nCRT). Literature data suggests that a better response to nCRT (greater tumour regression) leads to improved overall survival rates (OS) and disease-free survival rates (DFS). Tumour response to nCRT can be assessed either through clinical or pathological examination. The clinical tumour response is evaluated via a digital rectal examination, endoscopy (with or without ultrasound) and DWI-MRI. Our goal was to see if, when evaluating the clinical response to neoadjuvant chemoradiotherapy we can rely on the endoscopic findings and if it could have a predictive value for the overall outcomes.

Method:A retrospective study was performed on 43 patients that were treated for rectal cancer in our clinic following neoadjuvant chemoradiotherapy. We divided the patients into two groups regarding the endoscopy grading.

Results: Patients with a better response (endoscopy good grade) had a better disease free survival rate and lower recurrence rate compared to patients with a endoscopy low grade (86,5\% vs $56,6 \%)$ and $(10.34 \%$ vs $42,85 \%)$.

Conclusion: Endoscopy could be a useful tool in appreciating the tumour response to nCRT, and further research is needed in determining the best method for evaluating clinical response to neoadjuvant therapy in patients with rectal cancer.
\end{abstract}

Key words: rectal cancer, neoadjuvant, chemoradiotherapy, endoscopy

\section{Introduction}

Cancer represents the second cause of death worldwide and in 2015 was responsible for over 8,7 million deaths (1). Following breast cancer and lung cancer, colo-rectal cancer was ranked the 3rd most common cancer worldwide causing 850.000 deaths in 2015 (2). Around one third of these cases are rectal cancer. A multidisciplinary approach has become the cornerstone in the treatment of rectal cancer. Neoadjuvant chemoradiotherapy should reduce tumour bulk, minimise the risk of local recurrence, prevent disease dissemination from the local site, convert inoperable tumours and increase sphincter preservation. $(3,4)$. Standard treatment for rectal cancer according to numerous international guidelines recommends neoadjuvant chemoradio- therapy (nCRT). Neoadjuvant therapy can also lead to a higher rate of pathologic complete response (pCR) (5-.7). Literature data suggests that a better response to nCRT (greater tumour regression) leads to improved overall survival rates (OS) and disease-free survival rates (DFS). Therefore, a new focus of interest for current research is represented by the pathologic complete response rate and factors that may predict it. The response to $\mathrm{nCRT}$ is of a various heterogeneity and even if those with a good response to nCRT will probably have a better chance of a good oncological outcome, or sphincter preservation, there are still patients with limited to no tumour response to nCRT. These patients, without benefiting from nCRT may suffer from an increase rate of morbidity (sexual dysfunction, urinary and fecal incontinence) or 
even mortality (vascular or infectious causes) secondary to the nCRT toxicity (8-11). The percentage of patients that will have little to no response following nCRT can vary up to $25^{-}$ $45 \%$ (12), on the other hand a pathologic complete response (dependent on a surgical specimen) has been found in 15 to $27 \%$ patients (7). Tumour response to nCRT can be assessed either through clinical or pathological examination. The clinical tumour response is evaluated via a digital rectal examination, endoscopy (with or without ultrasound) and DWI-MRI. It doesn't have a prcise definition and varies through literature data (13). The optimal therapeutic sequent remains a challenge when faced with rectal cancer. The possibility of predicting the clinical and, or the pathological response to neoadjuvant treatment can lead to a better understanding of the current treatment options and maybe adjusting them to a patient centred strategy.

Our goal was to see if, when evaluating the clinical response to neoadjuvant chemoradiotherapy we can rely on the endoscopic findings and if it could have a predictive value for the overall outcomes.

\section{Methods}

We performed a retrospective study, selecting stage II and III adenocarcinoma rectal patients that were treated with neoadjuvant chemoradiotherapy between January 2015and January 2017. For all the patients the surgical procedure was performed in the General Surgery Clinic of the Bucharest "Carol Davila" Clinical Nephrology Hospital, and all endoscopic procedures were performed by 2 surgeons from this department. Data was collected regarding age, sex, tumour location, histopathology, endoscopy, staging, surgical procedure, laboratory findings, imagistic reports, and neoadjuvant therapy. Clinical response was evaluated using clinical examination through rectal digital examination and endoscopy or imagistic evaluation. A complete clinical response was considered when digital examination showed no palpable tumour and endoscopy revealed a flat healed scar, no visible pit or nodule.

Patients received long course chemoradiotherapy with 5 fluorouracil and radiotherapy of 50.4 Gy delivered in 28 fractions. Surgery followed at 6-8 weeks. Surgical procedures consisted of anterior resection or abdominoperineal resection either open or laparoscopically. Follow up consisted of clinical examination, CEA levels and endoscopy every 3 months the first year, and every 6 months the following 2 years, and annually after that, with CT/MRI annually. We used a two stage grading for the endoscopy findings: EGG(Endoscopy good grade) meaning either a complete response or a good response with endoscopy findings such as eritema or telangectasia, clean ulcer at the base, no elevation and ELG (Endoscopy low grade) moderate to no response and was defined by the presence of remnant tumour, stricture, ulcer with elevation or nodule. The two groups consisted of 29 patients for the good grade group (EGG) and 14 patients for the low grade group (ELG). We used GraphPad Prism version 7.00 for Windows, GraphPad Software, La Jolla California USA, www.graphpad.com, for statistical analysis. The overall survival rate (OS) and the disease-free survival rate (DFS) were analysed using the Kaplan-Meier curve. Clinical staging was performed according to the guidelines. We performed statistical analysis to evaluate the correlation between endoscopic group paring and overall results. We analysed only the correlation between endoscopy grading and OS and DFS. Further parameters such as pathologic response grouping and correlation with endoscopy grade group would have required a larger number of patients. Our intent was to evaluate if endoscopy grouping could be corelated with overall results, considering this was a retrospective study, and the surgical decision and overall treatment strategies were performed according to the multidisciplinary team consensus following international guidelines. 


\section{Results}

A total of 43 patients were included in this study. $61 \%$ of the patients were males (26) and $39 \%$ were females (17). The mean age was 64,2 years (41-87). Follow up duration was $24^{-}$ 36 months. At diagnosis 20 patients were clinical stage II, 23 patients were stage III. Tumour location: 19 low rectum, 18 mid rectum and 6 upper rectum. Histology grading 5patients G1, 25 patients G2, 8 patients G3 and 5 patients G4. Disease free survival rate for the 3 year follow up was $86,04 \%$. During the follow up period recurrence occurred in 9 patients (4 local and 5 distant metastasis).

The two groups of patients were compared regarding $\mathrm{T}$ stage, $\mathrm{N}$ stage and recurrence rate - disease-free survival rate.

In the EGG group 8 patients $(27.58 \%)$ were either T3 or T4 (after surgical excision), 7 (24.13\%) had remnant lymph nodes after nCRT. In the ELG group 10 patients $(71 \%)$ were either T3 or T4 (after surgery) and 8 patients $(57 \%)$ had remnant lymph nodes. Out of the 29th patients in the EGG group, 22 patients had G1 or G2 grading (75\%), and out of the 14th patients of the ELG group 7 patients were G1 or G2 (50\%). Recurrence rate was $10.34 \%$ for EGG and $42.85 \%$ for ELG, statistically significant $(p=0.026) .36$ months disease free survival rate vas $87.35 \%$ for $\mathrm{EGG}$ and $53.58 \%$ for ELG group, the difference was considered statistically significant $(p=0.018)$. Calculating the univariate proportional hazard ratio, the low endoscopy grading was the only factor statistically significant, for poor disease-free survival rate $(\mathrm{HR}=2.95)$. General characteristics and results grouped by Endoscopy grading are shown in Table 1 and Table 2 .

The patients within the EGG group were prone to a better outcome regarding the recurrence and disease-free survival rate. We aimed to evaluate the tumour response using endoscopy staging and integrate these findings with the overall long-term outcomes. The study has limitations regarding number of patients, and the fact that it is a retrospective single centre study. Also, the scoring
Table 1. Baseline Characteristics

\begin{tabular}{lc}
\hline Characteristics & Patients $(\mathbf{n = 4 3 )}$ \\
\hline Sex & \\
Male & $26(61 \%)$ \\
Female & $17(39 \%)$ \\
\hline Mean Age & 64.2 years $(41-87)$ \\
\hline Location & \\
Upper & 6 \\
Mid & 18 \\
low & 19 \\
\hline Stage & \\
II & 20 \\
III & 23 \\
\hline G Grading & \\
Well differentiated & 5 \\
Moderate differentiated & 25 \\
Poorly differentiated & 8 \\
Undifferentiated & 5 \\
\hline
\end{tabular}

system is subjective to the evaluating endoscopist. The results indicate that the low endoscopic grading represents an independent risk factor for poor disease-free survival rate with a hazard ratio of 2.95. Another limitation is represented by the fact that the endoscopy can evaluate the response to the neoadjuvant therapy but it cannot evaluate tumour pathologic specifics such as the G grade, which may be accountable for the better results in the EGG group (Figs. 1, 2).

\section{Discussion}

Neoadjuvant chemoradiotherapy is a therapy option that has been proven to reduce local recurrence (followed by TME procedure) and increase the rates of sphincter preservation. Studies have shown that pathological complete response following nCRT as evaluated by MRI or surgical specimen has been corelated

Table 2. Results grouped by Endoscopy grading

\begin{tabular}{lc}
\hline EGG $(\mathbf{n}=\mathbf{2 9})$ & ELG $(\mathbf{n}=\mathbf{1 4})$ \\
\hline DFS $87.3 \%$ & $53.5 \%->$ HR 2.95 \\
\hline LR $10.34 \%$ & LR $42.85 \%$ \\
\hline T3/T4 27.58\% & T3/T4 $71 \%$ \\
\hline$N+24.13 \%$ & $N+57 \%$ \\
\hline G1-G2 75\%(n=22) & G1-G2 $50 \%(n=7)$ \\
\hline
\end{tabular}

EGG - Endoscopy good grade, ELG - Endoscopy low grade 


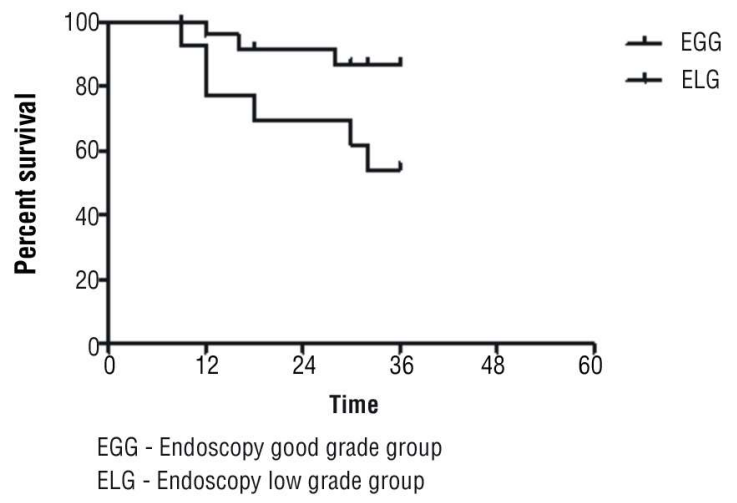

Figure 1. Endoscopy Grade Groups disease free survival rate

with better long-term outcomes in patients with rectal cancer (14-16). The response to nCRT can be used as a prognostic factor and can probably decide strategic treatment options. There has not been an optimal technique in accurately predicting the response to nCRT. Limited data has been published for the existing strategies such as: MRI, PET CT, Endoscopy, EUS, and molecular and biological markers. Clinical factors also wager in (digital rectal examination, clinical staging, T, and $\mathrm{N}$ status, CEA levels, tumour site, interval between nCRT and surgery). Byung-HEE KANG et al proposed a nomogram for predicting the pathological tumour response to neoadjuvant chemoradiotherapy (17). Their findings state that factors associated with a good clinical response could be: low $\mathrm{T}$ and $\mathrm{N}$ stage, low CEA levels, small diameter of the primary tumour, interval $>6$ weeks between neoadjuvant therapy and surgery.

The pathologic complete response rate varies but represents a valuable method of comparison between treatment strategies and also can act help tailor the patient's treatment strategy. To determine the pathologic response a surgical specimen is necessary. We focused on determining the clinical response. A complete clinical response is defined as the absence of detectable residual lesion assessed either by clinical examination or using endoscopy or imagistics. The clinical complete response rate has been reported to be associated with the pathologic complete response $(10-45 \%)(18,19)$. Kong et al recently published a systematic review and reported variability in the definition of clinical complete response (20). The Habr-Gama description (21) is widely accepted, and complete clinical responders can present as: decreased pliability within the rectal wall where the scar is present, telangiectasias or whitening of the mucosa with no visualizable or palpable tumour. Another prospective study that assessed clinical response endoscopically proved an association between clinical complete response and pathological complete response with an accuracy of $88,7 \%(22)$. There are authors that suggested the definition of clinical complete response after
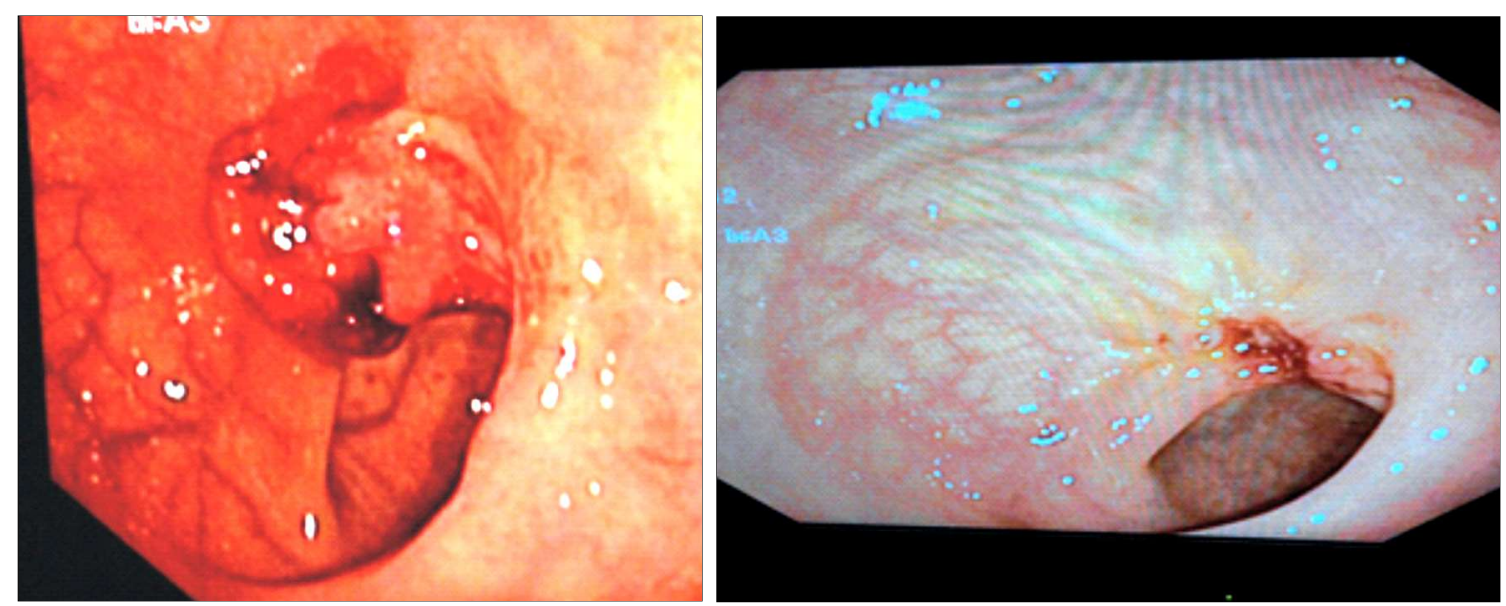

Figure 2. Patient with a complete response to nCRT (before and after) 
biopsy report. (23,24). Perez et al concluded that biopsies have a very low negative predictive value following nCRT (25).

\section{Conclusion}

Neoadjuvant therapy represents a gold standard for treating locally advanced rectal cancer. The response to neoadjuvant therapy varies significantly, but a better understanding of its variation will lead to a more patient centred approach. There is no consensus regarding a method to evaluate the clinical response to nCRT. Clinical and pathologic response are linked to a certain degree, however pathologic response depends on a surgical specimen. Tailoring the therapy before surgery could prove to be efficient especially for patients that will be considered at risk following nCRT. Furthermore, sphincter preservation ratio could also be improved by a better patient selection. Consensus amongst rectal cancer guidelines has been achieved but to a certain point, and a method of evaluating clinical response that would be widely approved could lead to uniformization in the therapeutic results obtained after neoadjuvant therapy worldwide. Endoscopy is a safe and accessible method, which doesn't require comprehensive logistics support and can be used widely. Endoscopy could become a useful tool in appreciating the tumour response to nCRT, and further research is needed in determining the best method for evaluating clinical response to neoadjuvant therapy in patients with rectal cancer. However actual clinic scenarios rely on the multidisciplinary team approval of therapeutic strategies. Endoscopy is usually doubled by imagistic staging such as CT or MRI, and patient therapeutic decision are considered within international guidelines consensus that are based on complete staging. Therefore, endoscopy alone, at the moment, is not recommended as a therapeutic strategy decision maker. Whether or not multidisciplinary teams will be able to apply patient centred therapeutic decisions that are based only on clinical response to neoadjuvant chemoradiotherapy is a question yet to be answered, but research is still needed regarding all aspects of clinical and imagistic evaluation (DWI-MRI, EUS, CT, Endoscopy) since all have proven to be useful in the better understanding of the heterogeneity involved in the tumour response to nCRT.

\section{Conflict of Interest}

The authors declare no conflicts of interests.

\section{References}

1. GBD 2015 Mortality and Causes of Death Collaborators. Global, regional, and national life expectancy, all-cause mortality, and cause-specific mortality for 249 causes of death, 1980-2015:a systematic analysis for the Global Burden of Disease Study 2015. Lancet. 2016;388(10053):1459-1544.

2. Fitzmaurice $\mathrm{C}$, Allen $\mathrm{C}$, Barber RM, Barregard L, Bhutta ZA, Brenner $\mathrm{H}$, et al. Global, regional, and national cancer incidence, mortality, years of life lost, years lived with disability, and disability-adjusted life-years for 32 cancer groups, 1990 to 2015: a systematic analysis for the global burden of disease study. JAMA Oncol. 2017;3(4):524-548.

3. Group, Colorectal Cancer Collaborative. Adjuvant radiotherapy for rectal cancer: a systematic overview of 8507 patients from 22 randomised trials. Lancet. 2001;358(9290):1291-304.

4. van Gijn W, Marijnen CAM, Nagtegaal ID, Meershoek-Klein Kranenbarg E, Putter H, Wiggers T, et al. Preoperative radiotherapy combined with total mesorectal excision for resectable rectal cancer: 12-year follow-up of the multicentre, randomised controlled TME trial. Lancet Oncol. 2011:12(6):575-82.

5. National Comprehensive Cancer Network Gudeliness Rectal Cancer, Version 3, 2015, www.nccn.org

6. Sauer R, Liersch T, Merkel S, Fietkau R, Hohenberger W, Hess C, et al. Preoperative versus postoperative chemoradiotherapy for locally advanced rectal cancer: results of the German CAO/ARO/ AIO-94 randomized phase III trial after a median follow up of 11 years. J Clin Oncol. 2012;30(16):1926-33.

7. Maas M, Nelemans PJ, Valentini V, Das P, Rödel C, Kuo LJ, et al. Long-term outcome in patients with a pathological complete response after chemoradiation for rectal cancer: a pooled analysis of individual patient data. Lancet Oncol. 2010;11(9):835-44.

8. Colorectal Cancer Collaborative G: Adjuvant radiotherapy for rectal cancer: A systematic overview of 8,507 patients from 22 randomised trials. Lancet. 2001;358(9290):1291-304.

9. Ho VP, Lee Y, Stein SL, Temple LKF. Sexual function after treatment for rectal cancer: a review. Dis Colon Rectum. 2011;54(1):113-25.

10. Stephens RJ, Thompson LC, Quirke P, Steele R, Grieve R, Couture $\mathrm{J}$, et al. Impact of short-course preoperative radiotherapy for rectal cancer on patients' quality of life: data from the Medical Research Council CR07/National Cancer Institute of Canada Clinical Trials Group C016 randomized clinical trial. J Clin Oncol. 2010;28(27): 4233-9.

11. Wiltink LM, Nout RA, van der Voort van Zyp JR, Ceha HM, Fiocco $M$, Meershoek-Klein Krannenbarg E, et al. Long term health related quality of life in patients with rectal cancer after preoperative shortcourse and long-course chemo radiotherapy. Clin Colorectal Cancer 15(3):e93-99, 2016

12. Valentini V, Coco C, Cellini N, Picciocchi A, Fares MC, Rosetto ME, et al. Ten years of preoperative chemoradiation for extraperitoneal T3 rectal cancer: acute toxicity, tumor response and sphincter 
preservation in three consecutive studies. Int $\mathrm{J}$ Radiat Oncol Biol Phys. 2001;51(2):371-83.

13. Glynne-Jones R, Hughes R. Critical appraisal of the "wait and see" approach in rectal cancer for clinical complete responders after chemoradiation. Br J Surg. 2012;99(7):897-909.

14. Patel UB, Taylor F, Blomqvist L, Blomqvist L, George C, Evans H, et al. Magnetic resonance imaging-detected tumour response for locally advanced rectal cancer predicts survival outcomes: MERCURY experience. J Clin Oncol. 2011;29(28):3753-60.

15. Siddiqui MRS, Bhoday J, Battersby NJ, Chand M, West NP, Abulafi Al-Mutaz, et al. Defining response to radiotherapy in rectal cancer using magnetic resonance imaging and histopathological scales. World J Gastroenterol. 2016;22(37):8414-8434.

16. Park IJ, You YN, Agarwal A, Skibber JM, Rodriguez-Bigas MA, Eng C, et al. Neoadjuvant treatment response as an early response indicator for patients with rectal cancer. J Clin Oncol. 2012;30(15): 1770-6.

17. Kang BH, Song C, Kang SB, Lee KW, Lee HS, Kim JS. Nomogram for predicting the pathological tumour response from pretreatment clinical characteristics in rectal cancer. Anticancer Res. 2020;40(4):2171-2177.

18. Glynne-Jones R, Wallace M, Livingstone JIL, Meyrick-Thomas J. Complete clinical response after preoperative chemoradiation in rectal cancer: is a "wait and see" policy justified? Dis Colon Rectum. 2008;51(1):10-9; discussion 19-20.

19. Hiotis SP, Weber SM, Cohen AM, Minsky BD, Paty PB, Guillem JG, et al. Assessing the predictive value of clinical complete response to neoadjuvant therapy for rectal cancer: an analysis of 488 patients. J Am Coll Surg. 2002;194(2):131-5; discussion 135-6.

20. Kong JC, Guerra GR, Warrier SK, Ramsay RG, Heriot AG. Outcome and salvage surgery following "watch and wait" for rectal cancer after neoadjuvant therapy: a systematic review. Dis Colon Rectum. 2017;60(3):335-345.

21. Habr-Gama A, Perez RO, Wynn G, Marks J, Kessler H, GamaRodrigues J. Complete clinical response after neoadjuvant chemoradiation therapy for distal rectal cancer: characterization of clinical and endoscopic findings for standardization. Dis Colon Rectum. 2010;53(12):1692-8.

22. Lim SG, Kim YB, Oh SY. Clinical significance of the endoscopic finding in predicting complete tumor response to preoperative chemoradiation therapy in rectal cancer. World J Surg. 2016; 40(12):3029-34.

23. Appelt AL, Pløen J, Harling H, Jensen FS, Jensen LH, Jørgensen JCR, et al. High-dose chemoradiotherapy and watchful waiting for distal rectal cancer: a prospective observational study. Lancet Oncol. 2015;16(8):919-27.

24. Nakagawa WT, Rossi BM, de 0 Ferreira F, Ferrigno R, David Filho WJ, Nishimoto IN, et al. Chemoradiation instead of surgery to treat mid and low rectal tumors: is it safe? Ann Surg Oncol. 2002; 9(6):568-73.

25. Perez RO, Habr-Gama A, Pereira GV, Lynn PB, Alves PA, Proscurshim I, et al. Role of biopsies in patients with residual rectal cancer following neoadjuvant chemoradiation after downsizing: can they rule out persisting cancer? Colorectal Dis. 2012;14(6):714-20. 